\title{
ANALISIS DAYA DUKUNG PONDASI BORE PILE BERDASARKAN DATA SONDIR PADA PROYEK PEMBANGUNAN INSTALASI IBU KOTA KECAMATAN(IKK) PERUSAHAAN DAERAH AIR MINUM (PDAM) KABUPATEN TANAH LAUT
}

\author{
Hendra Cahyadi ${ }^{1}$, Akhmad Gazali ${ }^{2}$, Firman Al Hakim ${ }^{3}$ \\ ${ }^{123}$ Universitas Islam Kalimantan MAB Banjarmasin \\ *Corresponding author: irarizqonroyan@gmail.com/HP.+628125027541
}

\begin{abstract}
ABSTRAK
Penyelidikan geoteknik merupakan pekerjaan yang menghasilkan data - data penunjang dalam pekerjaan perencanaan suatu bangunan. Didalam kegiatan perencanaan, penyelidikan geoteknik harus dilakukan secara baik sehingga dihasilkan gambaran yang jelas mengenai index properties dan engineering properties dari tanah. Analisis geoteknik dilakukan untuk dapat mengetahui stabilitas dan daya dukung tanah dalam menerima beban struktur diatasnya. Untuk mengetahui struktur tanah dan daya dukung tanah di lokasi perencanaan proyek pembangunan Instalasi Ibu Kota Kecamatan (IKK) Pelaihari Perusahaan Daerah Air Minum Kabupaten Tanah Laut maka dilakukan analisis perhitungan daya dukung tanah menggunakan data sondir dari dua titik sondir dengan menggunakan tiga metode yaitu metode Van Der Ween, metode Philipponant, dan metode Mayerhoff. Berdasarkan hasil perhitungan nilai daya dukung pondasi bore pile dengan menggunakan tiga metode dihasilkan nilai daya dukung yang berbeda - beda. Untuk perhitungan menggunakan metode Van Der Ween hasil nilai daya dukung ultimit ( $\left.\mathrm{Q}_{\mathrm{ult}}\right) 213.20$ ton dengan daya dukung izin $\left(\mathrm{Q}_{\mathrm{izin}}\right)$ 71.06 ton untuk titik sondir S.02 dan 193.52 ton dengan daya dukung izin $\left(Q_{\text {izin }}\right)$ 64,50 ton untuk titik sondir S.03. Perhitungan menggunakan metode Philipponant hasil nilai daya dukung ultimit ( $\left.Q_{u l t}\right) 136.51$ ton dengan daya dukung izin $\left(Q_{\text {izin }}\right)$ 45,50 ton untuk titik sondir S.02 dan 135, 06 ton dengan daya dukung izin ( $\left.Q_{\text {izin }}\right) 45,02$ ton untuk titik sondir S.03. Dan untuk perhitungan metode Mayerhoff hasil nilai daya dukung ultimit $\left(\mathrm{Q}_{\text {ult }}\right) 654.37$ ton dengan daya dukung izin $\left(\mathrm{Q}_{\text {izin }}\right)$ 218,12 ton untuk titik sondir S.02 dan 702.73 ton dengan daya dukung izin ( $\left.Q_{\text {izin }}\right)$ 234,24 ton untuk titik sondir S.03.
\end{abstract}

Kata Kunci: sondir, daya dukung, Van Der Ween, Philipponant, Mayerhoff

\section{ABSTRACT}

Geotechnical investigation work is one of the jobs that produces supporting data in planning a building work. In planning activities, geotechnical investigations must be carried out properly so as to produce a clear picture of the index property and engineering properties of the soil. Geotechnical analysis is carried out to be able to see the stability and bearing capacity of the soil in accepting structural loads above 
it. To see the structure of the soil and the carrying capacity of the soil at the location of the Pelaihari Regional Capital City Water Supply Company (IKK) development project in Tanah Laut Regency, an analysis of the calculation of the carrying capacity of the soil was carried out using sondir data from two sondir points using three methods, namely the Van Der method. Ween, the Philipponant method, and the Mayerhoff method. Based on the calculation of the bearing capacity value of the bore pile foundation using three methods, the resulting bearing capacity values are different. To calculate using the Van Der Ween method the results of the ultimate carrying capacity (Qult) 213.20 tonnes with the carrying capacity of the permit (Qizin) 71.06 tonnes for sondir points S.02 and 193.52 tonnes with permit carrying capacity (Qizin) 64, 50 tons for the sondir point S 0.03. The calculation using the Philipponant method results in the ultimate carrying capacity (Qult) of 136.51 tonnes with the carrying capacity of the permit (Qizin) 45.50 tonnes for the sondir point S.02 and 135.06 tonnes with the permit carrying capacity (Qizin) of 45.02 tonnes for the sondir point S.03. And for the calculation of the Mayerhoff method the results of the ultimate carrying capacity (Qult) of 654.37 tonnes with the carrying capacity of the permit (Qizin) 218.12 tonnes for sondir points S.02 and 702.73 tonnes with permit carrying capacity (Qizin) 234.24 tonnes for the sondir point $S 0.03$.

Key word: sondir, bearing capasity, Van Der Ween, Philipponant, Mayerhoff

\section{PENDAHULUAN}

Pekerjaan penyelidikan tanah merupakan salah satu pekerjaan yang menghasilkan data - data penunjang dalam pekerjaan perencanaan suatu bangunan. Didalam kegiatan perencanaan, penyelidikan tanah harus dilakukan secara baik sehingga dihasilkan gambaran yang jelas mengenai index properties dan engineering properties dari tanah. Penyelidikan tanah dari suatu daerah dapat dilakukan dengan baik apabila mengikuti prosedur yang baik dan benar sehingga data - data yang diperoleh dari hasil penyelidikan geoteknik merupakan data - data yang akurat dan dapat dipercaya. Dari data - data ini nantinya didapat suatu analisa teknis yang tepat mengenai tipe dan metode pelaksanaan yang paling cocok untuk suatu bangunan sipil yang akan didirikan pada daerah tersebut. Dalam hal ini, rencana pembangunan gedung merupakan salah satu bangunan sipil yang sangat memerlukan penyelidikan tanah didalam kegiatan perencanaan. Analisis daya dukung dilakukan untuk dapat mengetahui nilai daya dukung dalam menerima beban struktur diatasnya, daya dukung tanah penting bagi bangunan di atasnya. Salah satu parameter daya dukung dapat dilihat berdasarkan perhitungan menggunakan data uji sondir. Termasuk di dalamnya mengidentifikasi perilaku dan sifat teknis tanah sebelum pembangunan juga memprediksi perubahan perilaku dan sifat teknis tanah setelah pembangunan. Setiap kegiatan pembangunan yang dilakukan di atas permukaan tanah akan menimbulkan reaksi dari tanah tempat bangunan - bangunan tersebut ditempatkan.

Pondasi merupakan struktur bawah bangunan yang berfungsi sebagai penyalur beban 
di atasnya kelapisan tanah pendukung. Daya dukung pondasi didapatkan dari hasil penyelidikan tanah yang berupa tes sondir. Teknik sondir merupakan teknik penduga lapisan dalam tanah untuk menentukan jenis pondasi yang nanti akan digunakan seperti pondasi bore pile. Untuk mengetahui struktur tanah dan daya dukung pondasi bore pile di lokasi perencanaan proyek pembangunan Instalasi Ibu Kota Kecamatan (IKK) Pelaihari maka dilakukan analisis daya dukung tanah menggunakan data sondir menggunakan tiga metode yaitu metode Van Der Ween, metode Philipponant, dan metode Mayerhoff.

\section{METODE PENELITIAN}

Lokasi penelitian dilakukan di Kantor PDAM Kab. Tanah Laut. Tahapan penelitian berdasarkan diagram alir dijelaskan pada penjelasan sebagai berikut:

Menentukan penggunaan metode perhitungan daya dukung pondasi bore pile. Permasalahan dalam penelitian ini adalah bagaimana hasil penyelidikan tanah dan dan perhitungan daya dukung pondasi bore pile berdasarkan data sondir. Perhitungan daya dukung pondasi bore pile berdasarkan data sondir menggunakan tiga metode antara lain Metode Van Der Ween, Metode Philipphonant, dan Metode Mayerhoff.

\section{Pengumpulan data penelitian.}

Data yang digunakan adalah menggunakan data sekunder yaitu:

Data Sondir

Data Sondir yang digunakan untuk menganalisa beberapa metode yaitu data sondir titik S2 dan S3.

Data Pondasi Bore Pile

Denah pondasi bore pile digunakan untuk mengetahui titik mana saja yang nanti akan diobservasi penulis guna mengumpulkan data dalam penulisan ini. Denah pondasi dapat dilihat pada lampiran.

\section{Pengolahan data.}

Perhitungan daya dukung pondasi bore pile berdasarkan data sondir menggunakan tiga metode yang antara lain metode Van Der Ween, metode Philipphonant, dan metode Mayerhoff. Perhitungan daya dukung pondasi bore pile untuk mencari Qp dan Qs dari masing - masing metode kemudian dijumlahkan untuk mendapat Qult dari setiap metode yang digunakan.

\section{Analisis data.}

Tahapan analisa data pada penulisan ini adalah membaca hasil uji sondir untuk mengetahui hasil penyelidikan tanah dari uji sondir tersebut dan menghitung kapasitas daya dukung pondasi bore pile dengan menggunakan tiga metode yaitu metode Van Der Ween, Philipponant, dan Mayerhoff.

Tahapan proses yang akan dilakukan dalam penelitian ini digambarkan 
dalam diagram alir pada Gambar 1 sebagai berikut:

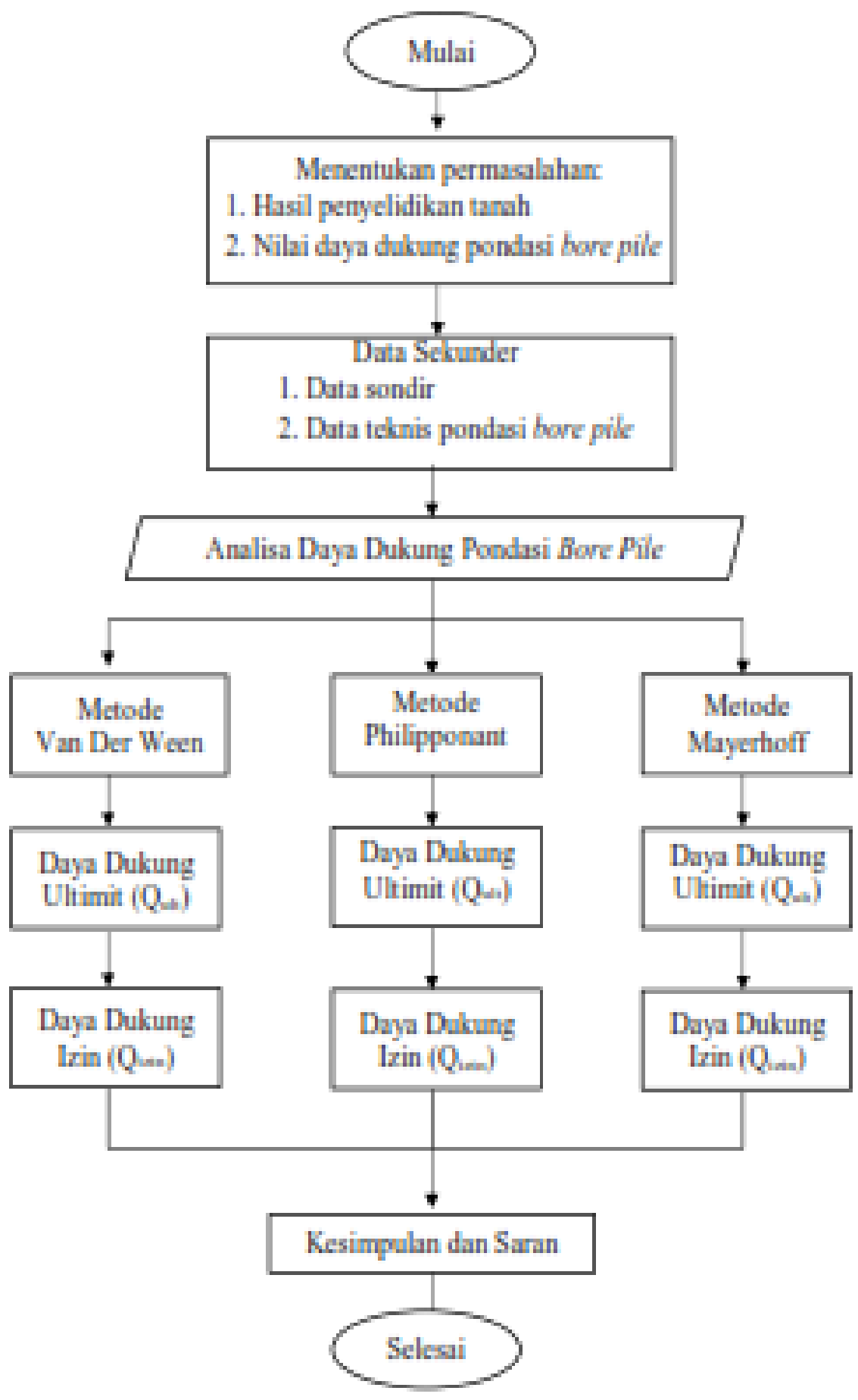

Gambar 1 Bagan Alir Penelitian

HASIL \& PEMBAHASAN 
JURNAL KACAPURI

JURNAL KEILMUAN TEKNIK SIPIL

Volume 3 Nomor 2 Edisi Desember 2020

\section{Hasil Penyelidikan Tanah (Soil Investigation)}

Dalam penelitian ini, uji penyelidikan tanah menggunakan uji sondir. Sondir yang dilakukan pada lokasi penelitian ada tiga titik. Namun dalam penelitian hanya menggunakan dua titik yaitu titik sondir kedua dan ketiga. Alasan tidak menggunakan titik sondir pertama karena berbeda lokasi dengan titik kedua dan ketiga. Berdasarkan data sondir, dapat diketahui profil jenis tanah dilokasi sebagai berikut:

Tabel 1 Data Sondir Titik Kedua (S02)

\begin{tabular}{|c|c|c|c|c|c|c|c|c|c|c|c|c|c|}
\hline $\begin{array}{l}\text { Depth } \\
\text { m }\end{array}$ & $\begin{array}{c}\mathrm{C} \\
\mathrm{kg} / \mathrm{cm}^{2}\end{array}$ & $\begin{array}{c}\mathrm{C}+\mathrm{F} \\
\mathrm{kg} / \mathrm{cm}^{2}\end{array}$ & $\begin{array}{c}F \\
\mathrm{~kg} / \mathrm{cm}\end{array}$ & $\begin{array}{l}\text { F.Tota } \\
\text { I }\end{array}$ & $\begin{array}{c}F \\
\mathrm{~kg} / \mathrm{cm}^{2}\end{array}$ & $\begin{array}{l}\mathbf{F r} \\
\%\end{array}$ & $\begin{array}{l}\text { Depth } \\
\text { m }\end{array}$ & $\begin{array}{c}\mathrm{C} \\
\mathrm{kg} / \mathrm{cm}^{2}\end{array}$ & $\begin{array}{c}\mathrm{C}+\mathrm{F} \\
\mathrm{kg} / \mathrm{cm}^{2}\end{array}$ & $\begin{array}{c}F \\
\mathrm{~kg} / \mathrm{cm}\end{array}$ & $\begin{array}{l}\text { F.Tota } \\
\text { I }\end{array}$ & $\begin{array}{c}F \\
\mathrm{~kg} / \mathrm{cm}^{2}\end{array}$ & $\begin{array}{l}\mathrm{Fr} \\
\%\end{array}$ \\
\hline 0.00 & 0.00 & 0.00 & 0.00 & 0.00 & 0.00 & 0.00 & 7.20 & 11.00 & 16.00 & 10.00 & 350.00 & 0.46 & $\ldots$ \\
\hline 0.20 & 40.00 & 45.00 & 10.00 & 10.00 & 0.46 & 1.14 & 7.40 & 11.00 & 16.00 & 10.00 & 360.00 & 0.46 & 4.15 \\
\hline 0.40 & 40.00 & 45.00 & 10.00 & 20.00 & 0.46 & 1.14 & 7.60 & 11.00 & 16.00 & 10.00 & 370.00 & 0.46 & 4.1 \\
\hline 0.60 & 30.00 & 35.00 & 10.00 & 30.00 & 0.46 & 1.52 & 7.80 & 11.00 & 18.00 & 14.00 & 384.00 & 0.64 & \\
\hline 0.80 & 30.00 & 35.00 & 10.00 & 40.00 & 0.46 & 1.52 & 8.00 & 12.00 & 18.00 & 12.00 & 396.00 & 0.55 & 4.57 \\
\hline 1.00 & 30.00 & 35.00 & 10.00 & 50.00 & 0.46 & 1.52 & 8.20 & 12.00 & 18.00 & 12.00 & 408.00 & 0.55 & 4.57 \\
\hline 1.20 & 40.00 & 45.00 & 10.00 & 60.00 & 0.46 & 1.14 & 8.40 & 20.00 & 25.00 & 10.00 & 418.00 & 0.46 & 2.2 \\
\hline 1.40 & 40.00 & 45.00 & 10.00 & 70.00 & 0.46 & 1.14 & 8.60 & 25.00 & 35.00 & 20.00 & 438.00 & 0.91 & \\
\hline 1.60 & 50.00 & 55.00 & 10.00 & 80.00 & 0.46 & 0.91 & 8.80 & 40.00 & 45.00 & 10.00 & 448.00 & 0.46 & 1. \\
\hline 1.80 & 60.00 & 65.00 & 10.00 & 90.00 & 0.46 & 0.76 & 9.00 & 40.00 & 50.00 & 20.00 & 468.00 & 0.91 & 2.2 \\
\hline 2.00 & 70.00 & 75.00 & 10.00 & 100.00 & 0.46 & 0.65 & 9.20 & 40.00 & 55.00 & 30.00 & 498.00 & 1.37 & 3 \\
\hline 2.20 & 125.00 & 130.00 & 10.00 & 110.00 & 0.46 & 0.37 & 9.40 & 40.00 & 55.00 & 30.00 & 528.00 & 1.37 & 3 \\
\hline 2.40 & 130.00 & 135.00 & 10.00 & 120.00 & 0.46 & 0.35 & 9.60 & 40.00 & 55.00 & 30.00 & 558.00 & 1.37 & 3. \\
\hline 2.60 & 90.00 & 95.00 & 10.00 & 130.00 & 0.46 & 0.51 & 9.80 & 50.00 & 80.00 & 60.00 & 618.00 & 2.74 & 5.4 \\
\hline 2.80 & 40.00 & 45.00 & 10.00 & 140.00 & 0.46 & 1.14 & 10.00 & 50.00 & 80.00 & 60.00 & 678.00 & 2.74 & \\
\hline 3.00 & 10.00 & 15.00 & 10.00 & 150.00 & 0.46 & 4.57 & 10.20 & 55.00 & 85.00 & 60.00 & 738.00 & 2.74 & 4.5 \\
\hline 3.20 & 10.00 & 15.00 & 10.00 & 160.00 & 0.46 & 4.57 & 10.40 & 55.00 & 85.00 & 60.00 & 798.00 & 2.74 & \\
\hline 3.40 & 20.00 & 25.00 & 10.00 & 170.00 & 0.46 & 2.28 & 10.60 & 55.00 & 75.00 & 40.00 & 838.00 & 1.83 & 3.3 \\
\hline 3.60 & 25.00 & 30.00 & 10.00 & 180.00 & 0.46 & 1.83 & 10.80 & 55.00 & 75.00 & 40.00 & 878.00 & 1.83 & 3.3 \\
\hline 3.80 & 25.00 & 30.00 & 10.00 & 190.00 & 0.46 & 1.83 & 11.00 & 5.00 & 80.00 & .00 & 928.00 & 28 & 4. \\
\hline 4.00 & 30.00 & 35.00 & 10.00 & 200.00 & 0.46 & 1.52 & 11.20 & 60.00 & 80.00 & 40.00 & 968.00 & 1.83 & \\
\hline 4.20 & 30.00 & 5.00 & 10.00 & 210.00 & 0.46 & 1.52 & 11.40 & 0.00 & 85.00 & .00 & 1018.00 & 28 & 3.8 \\
\hline $4.4 C$ & 15.00 & 00 & 10.00 & .00 & 0.46 & 3.05 & 11 & .00 & 85.00 & .00 & 3.00 & 28 & 3.81 \\
\hline 4.60 & 15.00 & 20.00 & 10.00 & 230.00 & 0.46 & 3.05 & 11.80 & 70.00 & 95.00 & 50.00 & 1118.00 & 2.28 & \\
\hline 4.8 & 10.00 & 00 & .00 & .00 & 0.46 & 4.57 & 12 & 0.00 & 95.00 & .00 & 1168.00 & 28 & \\
\hline 5.00 & 10.00 & 15.00 & 10.00 & 250.00 & 0.46 & 4.57 & 12.20 & 0.00 & 95.00 & 50.00 & 1218.00 & 2.28 & \\
\hline 5.20 & 11.00 & 15.00 & 8.00 & 258.00 & 0.37 & 3.32 & 12.40 & 100.00 & 125.00 & 50.00 & 1268.00 & 2.28 & \\
\hline 5.40 & 11.00 & 15.00 & 8.00 & 266.00 & 0.37 & 3.32 & 12.60 & 105.00 & 125.00 & 40.00 & 1308.00 & 1.83 & \\
\hline 5.60 & 10.00 & 15.00 & 10.00 & 276.00 & 0.46 & 4.57 & 12.80 & 105.00 & 125.00 & 40.00 & 1348.00 & 1.83 & \\
\hline 5.80 & 10.00 & 15.00 & 10.00 & 286.00 & 0.46 & 4.57 & 13.00 & 100.00 & 120.00 & 40.00 & 1388.00 & 1.83 & 1.8 \\
\hline 6.00 & 11.00 & 15.00 & 8.00 & 294.00 & 0.37 & 3.32 & 13.20 & 105.00 & 125.00 & 40.00 & 1428.00 & 1.83 & 1. \\
\hline 6.20 & 11.00 & 16.00 & 10.00 & 304.00 & 0.46 & 4.15 & 13.40 & 105.00 & 125.00 & 40.00 & 1468.00 & 1.83 & \\
\hline 6.40 & 11.00 & 16.00 & 10.00 & 314.00 & 0.46 & 4.15 & 13.60 & 200.00 & 250.00 & 100.00 & 1568.00 & 4.57 & 2. \\
\hline
\end{tabular}

Berdasarkan data sondir titik kedua (S02), dapat diperkirakan jenis tanah dilokasi 
JURNAL KACAPURI

JURNAL KEILMUAN TEKNIK SIPII

Volume 3 Nomor 2 Edisi Desember 2020

tersebut:

Tabel 2 Profil Jenis Tanah Berdasarkan Data Sondir Titik Kedua (S02)

\begin{tabular}{|c|l|}
\hline Kedalaman (meter) & \multicolumn{1}{c|}{ Jenis Tanah } \\
\hline $00.00-01.50$ & Lempung atau lempung kelanauan kenyal \\
\hline $01.50-02.60$ & Kerikil kepasiran lepas \\
\hline $02.60-05.00$ & Lempung atau lempung kelanauan \\
\hline $05.00-07.00$ & Pasir lepas \\
\hline $07.00-08.60$ & Lempung atau lempung kelanauan \\
\hline $08.60-11.00$ & Lempung atau lempung kelanauan kenyal \\
\hline $11.00-13.40$ & $\begin{array}{l}\text { Pasir padat, pasir kelanauan atau lempung padat } \\
\text { dan kerikil kelempungan. }\end{array}$ \\
\hline $13.40-13.80$ & Pasir padat, pasir kerikilan padat \\
\hline 13.80 kebawah & Tanah keras \\
\hline
\end{tabular}

Tabel 3 Data Sondir Titik Ketiga (S03)

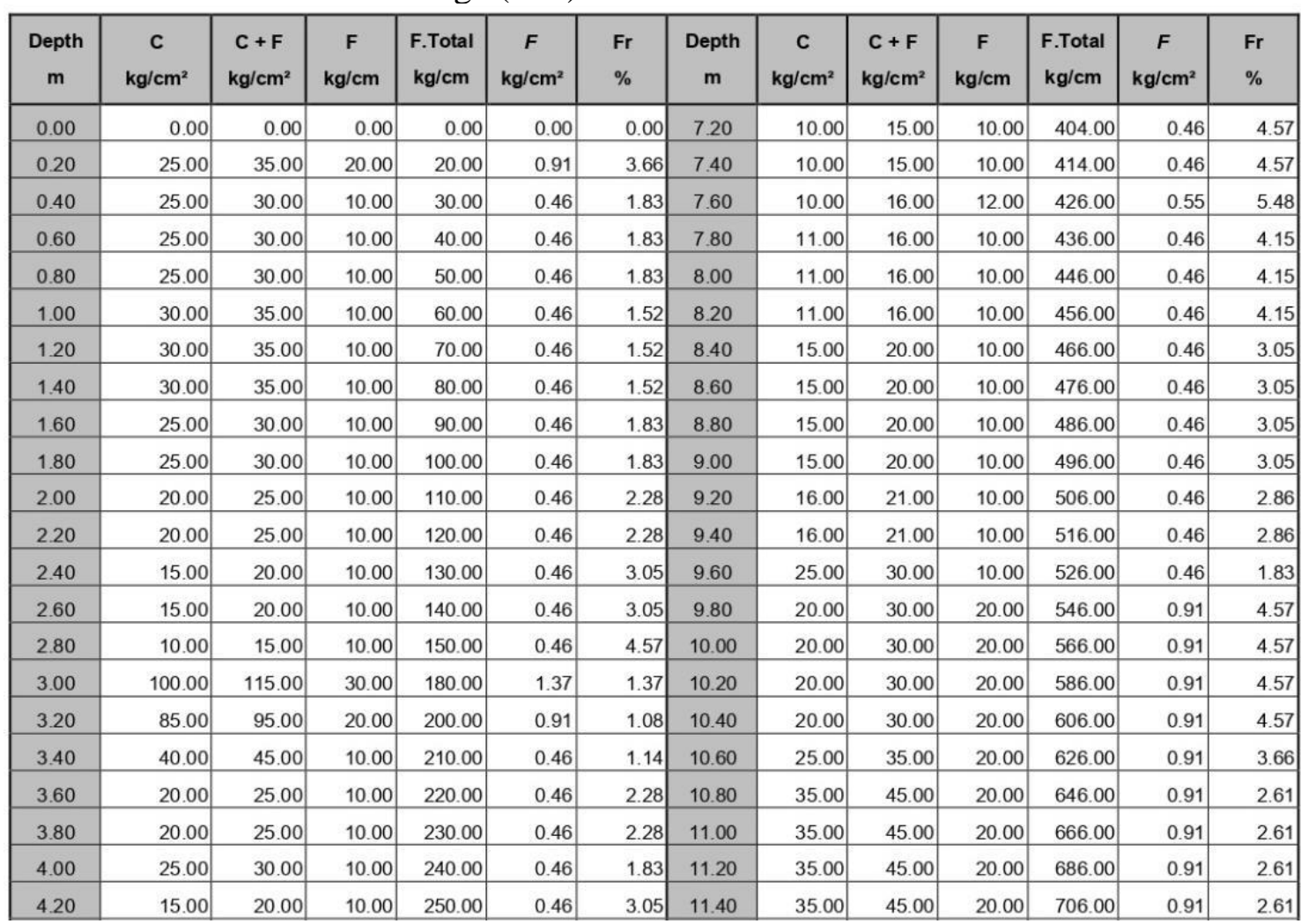


Tabel 4 Profil Jenis Tanah Berdasarkan Data Sondir Titik Ketiga (S03)

\begin{tabular}{|c|l|}
\hline Kedalaman (meter) & \multicolumn{1}{c|}{ Jenis Tanah } \\
\hline $00.00-02.80$ & Lempung atau lempung kelanauan \\
\hline $02.80-03.20$ & $\begin{array}{l}\text { Pasir padat, pasir kelanauan atau lempung padat } \\
\text { dan kerikil kelempungan }\end{array}$ \\
\hline $03.20-05.00$ & Lempung atau lempung kelanauan \\
\hline $05.00-07.00$ & Pasir lepas \\
\hline $07.00-09.60$ & Lempung atau lempung kelanauan \\
\hline $09.60-10.60$ & Lempung agak kenyal \\
\hline $10.60-13.00$ & Lempung atau lempung kelanauan kenyal \\
\hline $13.00-14.80$ & $\begin{array}{l}\text { Pasir padat, pasir kelanauan atau lempung padat } \\
\text { dan kerikil kelempungan }\end{array}$ \\
\hline $14.80-15.20$ & Pasir padat, pasir kerikilan padat \\
\hline 15.20 kebawah & Tanah keras \\
\hline
\end{tabular}

\section{Analisa Daya Dukung Pondasi Bore Pile Berdasarkan Data Sondir}

\section{Metode Van Der Ween}

Perhitungan pada titik sondir kedua (S02) pada kedalaman 13,80 meter. Data bore pile:

Diameter tiang (D) $\quad=50 \mathrm{~cm}$

Keliling bore pile $\quad=\pi \times 50 \mathrm{~cm}$

$$
=157 \mathrm{~cm}=1,57 \mathrm{~m}
$$

Luas bore pile $\quad=1 / 4 \times \pi \times 50^{2}$

$$
=1962,5 \mathrm{~cm}^{2}
$$

Hasil perhitungan daya dukung pondasi dengan Metode Van Der Ween dapat dilihat pada Tabel 5 berikut ini

Tabel 5 Perhitungan Daya Dukung Metode Van Der Ween

\begin{tabular}{|c|c|c|c|c|c|c|}
\hline Kedalaman & Qp & Qs & \multicolumn{2}{|c|}{ Qult } & \multicolumn{2}{c|}{ Qizin } \\
\hline $\mathbf{( m )}$ & $\mathbf{( K g )}$ & $\mathbf{( K g )}$ & $\mathbf{( K g})$ & (ton) & $\mathbf{( K g )}$ & (ton) \\
\hline 4 & $19.140,43$ & $58.727,81$ & $77.868,24$ & 77,87 & $25.956,08$ & 25,96 \\
\hline 6 & $11.871,91$ & $63.928,44$ & $75.800,35$ & 75,80 & $25.266,78$ & 25,27 \\
\hline 8 & $5.960,19$ & $68.295,00$ & $74.255,19$ & 74,26 & $24.751,73$ & 24,75 \\
\hline 10 & $19.140,43$ & $90.127,81$ & $109.268,24$ & 109,27 & $36.422,75$ & 36,42 \\
\hline 12 & $76.319,44$ & $119.565,31$ & $195.884,76$ & 195,88 & $65.294,92$ & 65,29 \\
\hline 13.8 & $82.264,43$ & $130.938,00$ & $213.202,00$ & 213,20 & $71.067,33$ & 71,07 \\
\hline
\end{tabular}

\section{Metode Philipponant}


Perhitungan pada titik sondir kedua (S02) pada kedalaman 13,80 meter. Data bore pile:

Diameter tiang (D) $=50 \mathrm{~cm}$

Keliling bore pile $\quad=\pi \times 50 \mathrm{~cm}$

$$
\begin{array}{cc} 
& =157 \mathrm{~cm}=1,57 \mathrm{~m} \\
\text { Luas bore pile } & =1 / 4 \times \pi \times 50^{2} \\
= & 1962,5 \mathrm{~cm}^{2}
\end{array}
$$

Hasil perhitungan daya dukung pondasi dengan Metode Philipponant dapat dilihat pada

Tabel 6 berikut ini

Tabel 6 Perhitungan Daya Dukung Metode Philipponant

\begin{tabular}{|c|c|c|c|c|c|c|}
\hline Kedalaman & Qp & Qs & \multicolumn{2}{|c|}{ Qult } & \multicolumn{2}{c|}{ Qizin } \\
\hline $\mathbf{( m )}$ & $\mathbf{( K g )}$ & $\mathbf{( K g )}$ & $\mathbf{( K g})$ & $\mathbf{( t o n )}$ & $\mathbf{( K g )}$ & (ton) \\
\hline 4 & $9.346,41$ & $15.700,00$ & $25.046,41$ & 25,05 & 8348,80 & 8,35 \\
\hline 6 & $3.385,31$ & $23.079,00$ & $26.464,31$ & 26,46 & 8821,44 & 8,82 \\
\hline 8 & $7.899,06$ & $31.086,00$ & $38.985,06$ & 38,99 & $12.995,02$ & 13,00 \\
\hline 10 & $16.435,94$ & $53.223,00$ & $69.658,94$ & 69,66 & $23.219,65$ & 23,22 \\
\hline 12 & $29.192,19$ & $91.688,00$ & $120.880,19$ & 120,88 & $40.293,40$ & 40,29 \\
\hline 13.8 & $49.226,04$ & $87.292,00$ & $136.518,00$ & 136,51 & $45.506,00$ & 45,51 \\
\hline
\end{tabular}

\section{Metode Mayerhoff}

Perhitungan pada titik sondir kedua (S02) pada kedalaman 13,80 meter. Data bore pile:

Diameter tiang $(\mathrm{D}) \quad=50 \mathrm{~cm}$

Keliling bore pile $\quad=\pi \times 50 \mathrm{~cm}$

$$
=157 \mathrm{~cm}=1,57 \mathrm{~m}
$$

Luas bore pile

$$
=1 / 4 \times \pi \times 50^{2}
$$$$
=1962,5 \mathrm{~cm}^{2}
$$

Hasil perhitungan daya dukung pondasi dengan Metode Mayerhoff dapat dilihat pada Tabel 7 berikut ini

Tabel 7 Perhitungan Daya Dukung Metode Mayerhoff

\begin{tabular}{|c|c|c|c|c|}
\hline Kedalaman & \multicolumn{2}{|c|}{ Qult } & \multicolumn{2}{c|}{ Qizin } \\
\hline (m) & (Kg) & (ton) & (Kg) & (ton) \\
\hline 4 & $90.275,00$ & 90,27 & $30.091,67$ & 30,09 \\
\hline 6 & $67.745,50$ & 67,74 & $22.581,83$ & 22,58 \\
\hline 8 & $85.722,00$ & 85,72 & $28.574,00$ & 28,57 \\
\hline 10 & $196.721,00$ & 196,72 & $65.573,67$ & 65,57 \\
\hline 12 & $320.751,00$ & 320,75 & $106.917,00$ & 106,92 \\
\hline 13.8 & $654.376,00$ & 654,37 & $21.8125,33$ & 218,13 \\
\hline
\end{tabular}

Secara keseluruhan, nilai daya dukung pondasi Bore Pile berdasarkan data sondir dengan menggunakan metode Van Der Ween, Philipponant dapat dilihat pada Tabel 8 dan Gambar 2 berikut ini 
Tabel 8 Hasil Nilai Daya Dukung Pondasi Bore Pile Berdasarkan Data Sondir Mengguakan Tiga Metode.

\begin{tabular}{|c|c|c|c|c|}
\hline Metode & $\begin{array}{c}\text { S.02 } \\
\text { Qult } \\
\text { (ton) }\end{array}$ & $\begin{array}{c}\text { S.02 } \\
\text { Qizin } \\
\text { (ton) }\end{array}$ & $\begin{array}{c}\text { S.03 } \\
\text { Qult } \\
\text { (ton) }\end{array}$ & $\begin{array}{c}\text { S.03 } \\
\text { Qizin } \\
\text { (ton) }\end{array}$ \\
\hline Van Der Ween & 213,20 & 71,06 & 193,52 & 64,50 \\
\hline Philipponant & 136,51 & 45,50 & 135,06 & 45,02 \\
\hline Mayerhoff & 654,37 & 218,12 & 702,73 & 234,24 \\
\hline
\end{tabular}

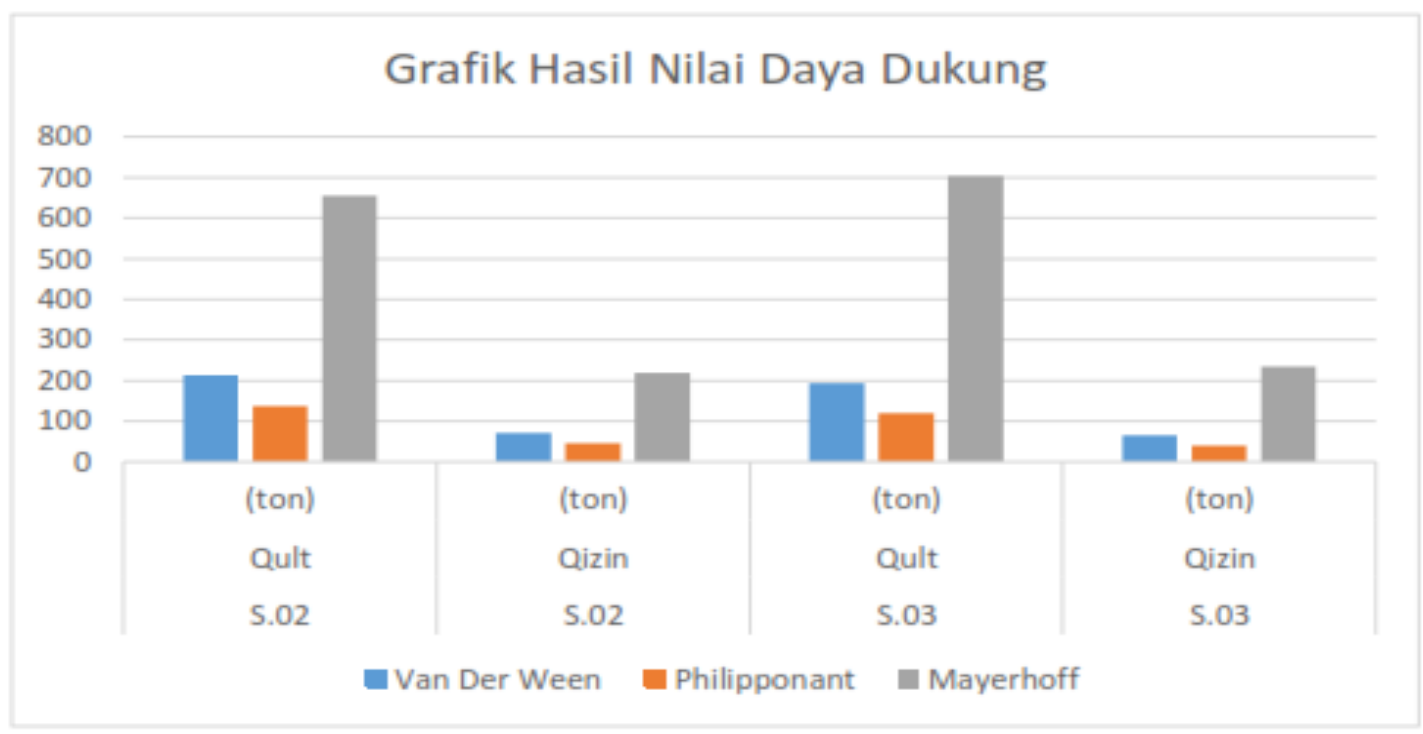

Gambar 2 Grafik Hasil Nilai Daya Dukung

Jadi, berdasarkan hasil perhitungan nilai daya dukung pondasi bore pile dengan menggunakan tiga metode dihasilkan nilai daya dukung yang berbeda - beda. Untuk perhitungan menggunakan metode Van Der Ween hasil nilai daya dukung ultimit ( $\left.Q_{u l t}\right)$ 213.20 ton dengan daya dukung izin $\left(\mathrm{Q}_{\text {izin }}\right) 71.06$ ton untuk titik sondir S.02 dan 193.52 ton dengan daya dukung izin ( $\left.\mathrm{Q}_{\mathrm{izin}}\right)$ 64,50 ton untuk titik sondir S.03. Perhitungan menggunakan metode Philipponant hasil nilai daya dukung ultimit ( $\left.\mathrm{Q}_{\mathrm{ult}}\right)$ 136.51 ton dengan daya dukung izin $\left(\mathrm{Q}_{\mathrm{izin}}\right)$ 45,50 ton untuk titik sondir $\mathrm{S} .02$ dan 135, 06 ton dengan daya dukung izin ( $Q_{\text {izin }}$ ) 45,02 ton untuk titik sondir S.03. Dan untuk perhitungan metode Mayerhoff hasil nilai daya dukung ultimit $\left(\mathrm{Q}_{\mathrm{ult}}\right) 654.37$ ton dengan daya dukung izin $\left(\mathrm{Q}_{\text {izin }}\right) 218,12$ ton untuk titik sondir S.02 dan 702.73 ton dengan daya dukung izin $\left(\mathrm{Q}_{\text {izin }}\right)$ 234,24 ton untuk titik sondir S.03.

\section{PENUTUP}

\section{Kesimpulan}

Dari analisis yang dilakukan, dapat diambil kesimpulan sebagai berikut: 
1. Daya dukung ultimit $\left(\mathrm{Q}_{\mathrm{ult}}\right)$ pondasi bore pile dengan metode Van Der Ween adalah 213,20 ton dengan daya dukung izin ( $\left.\mathrm{Q}_{\text {izin }}\right)$ 71,06 ton untuk titik kedua (S02) dan 193,52 ton dengan daya dukung izin ( $\left.\mathrm{Q}_{\text {izin }}\right)$ 64,50 ton untuk titik ketiga (S03).

2. Daya dukung ultimit $\left(\mathrm{Q}_{\mathrm{ult}}\right)$ pondasi bore pile dengan metode Philipponant adalah 136,51 ton dengan daya dukung izin ( $\left.\mathrm{Q}_{\mathrm{izin}}\right)$ 45,50 ton untuk titik kedua (S02) dan 135,06 ton dengan daya dukung izin ( $\left.\mathrm{Q}_{\mathrm{izin}}\right)$ 45,02 ton untuk titik ketiga (S03).

3. Daya dukung ultimit $\left(\mathrm{Q}_{\mathrm{ult}}\right)$ pondasi bore pile dengan metode Mayerhoff adalah 654,37 ton dengan daya dukung izin ( $\left.\mathrm{Q}_{\text {izin }}\right)$ 218,12 ton untuk titik kedua (S02) dan 702,73 ton dengan daya dukung izin ( $\left.\mathrm{Q}_{\text {izin }}\right)$ 234,24 ton untuk titik ketiga (S03).

\section{Saran}

Dari hasil kesimpulan diatas, saran yang dapat diberikan untuk hasil yang lebih baik adalah sebagai berikut:

1. Pengambilan data tanah diharapkan pada titik dimana diperkirakan akan menerima beban paling besar, sehingga akan menentukan keakuratan dalam perencanaan suatu bangunan.

2. Dalam perencanaan konstruksi, beban yang diteruskan ke pondasi tidak boleh melebihi nilai daya dukung pondasi karena mengakibatkan penurunan dan kerusakan pada konstruksi diatasnya.

3. Dalam perencanaan selanjutnya agar menggunakan metode perhitungan lain untuk membandingkan hasil dari metode - metode yang digunakan dalam perencanaan pondasi bore pile.

\section{DAFTAR PUSTAKA}

1. Agril, F. Analisa Perhitungan Daya Dukung Pondasi Tiang Pancang Dibandingkan Dengan Daya Dukung Hydraulik Jacking System Dan Pile Driving Analyzer (PDA) Test Pada Proyek Pembangunan Gedung Perpustakaan Sekolah Tinggi Agama Islam Negeri Kediri. Universitas Negeri Surabaya.

2. Andi, Y. 2014. Analisis Daya Dukung Pondasi Tiang Pancang Diverifikasi Dengan Hasil Uji Pile Driving Analyzer Test DAn Capwap. Universitas Bangka Belitung.Bowles, J.E. dan Hainim, J.K. 1991.Sifat-Sifat Fisik Dan Geoteknis Tanah (Mekanika Tanah). Jakarta: Penerbit Erlangga.

3. Badan Standarisasi Nasional. Cara Uji Penetrasi Lapangan Dengan Alat Sondir. SNI 2827 - 2008

4. Banta C. 2013. Analisa Daya Dukung Pondasi Dengan Moetoda SPT, CPT, Dan Mayerhof Pada Lokasi Rencana Konstruksi PLTU Nagan Raya Provinsi Aceh. Universitas Syiah Kuala.

5. Bowles, J.E. (1997). Analisis dan Desain Fondasi I, Edisi Keempat. Jakarta: Erlangga.

6. David A. Analisa Kapasitas Daya Dukung Pondasi Tiang Pancang Dengan Beban Vertikal Pada Proyek Pembangunan Gedung Dinas Prasarana Jalan, Tata 
Ruang,dan Permukiman Sumatera Barat, Universitas Bung Hatta.

7. Eko, S. 2015. Analisis Daya Dukung Tiang Pancang Dengan Menggunakan Metode Statik Dan Calendering. Universitas Sam Ratulangi. Manado.

8. Hardiyatmo, Hary Cristadi. 2002. Mekanika Tanah II. Erlangga. Jakarta.

9. Hendry, T.W. 2014. Analisis Pengujian Sondir Untuk Mengetahui Peningkatan Kekuaatan Tanah Sangat Lunak Di Lokasi Gate House Dalam Pekerjaan "Grouting At Semarang Pumping Statition And Retarding Pond"

10. Jesron, P. 2017. Analisis Daya Dukung Pondasi Tiang Pancang Pada Proyek Pembangunan Perhotelan, Apartemen, Kondominium di Jalan Ring Road Medan. Universitas Medan Area. Indonesia.

11. Lilik, GA. 2016. Analisa Daya Dukung Tiang Pancang Menggunakan Data Insitu Test, Parameter Laboratorium Terhadap Loading Test Kantledge. Universitas Muhammadiyah Jakarta.

12. Muhammad S. 2017. Perbandingan Daya Dukung Ultimit Tiang Pancang Antara Metode Teoritis Dan Metode Aktual Dengan Konfigurasi Tiang Dan Kedalaman. Politeknik Negri Banjarmasin. Bnjarmasin.

13. Najoan.2002. Interpretasi Hasil Uji dan Penyusunan Laporan Penyelidikan Geoteknik. Badan Litbang PU Departemen Pekerjaan Umum.

14. Renaldi, C. 2019. Analisis Daya Dukung Pondasi Enlarged Base Berdasarkan Data N-SPT Dengan Program Microsoft Excel. Universitas Tarumanagara. Sosrodarsono, Suyono dan Kazuto Nakazawa. 2000. Mekanika Tanah dan Teknik Pondasi. Pradnya Paramita, Jakarta.

15. Terzaghi, Karl dan Ralph B Peek.1993.Mekanika Tanah dalam Praktek Rekayasa Jilid2, Penerbit Erlangga, Jakarta.

16. Wahyudi, Herman. 1999. Daya Dukung Pondasi Dalam. Surabaya: Institut Teknologi Sepuluh Nopember. 